\title{
Esterase-sensitive prodrugs with tunable release rates and direct generation of hydrogen sulfide ${ }^{a}$
}

\author{
Yueqin Zheng ${ }^{\mathrm{b}}$, Bingchen $\mathrm{Yu}^{\mathrm{b}}$, Dr. Kaili $\mathrm{Ji}^{\mathrm{b}}$, Zhixiang Pan ${ }^{\mathrm{b}}$, Vayou Chittavong ${ }^{\mathrm{b}}$, and Prof. \\ Binghe Wang ${ }^{b}$ \\ Binghe Wang: wang@gsu.edu \\ bDepartment of Chemistry, Georgia State University, Atlanta, Georgia 30303-3083
}

\begin{abstract}
Prodrugs that release hydrogen sulfide upon esterase-mediated cleavage of an ester group followed by lactonization are described herein. By modifying the ester group and thus its susceptibility to esterase, and structural features critical to the lactonization rate, $\mathrm{H}_{2} \mathrm{~S}$ release rates can be tuned. Such prodrugs directly release hydrogen sulfide without the involvement of perthiol species, which are commonly encountered with existing $\mathrm{H}_{2} \mathrm{~S}$ donors. Additionally, such prodrugs can easily be conjugated to another non-steroidal anti-inflammatory agent, leading to easy synthesis of hybrid prodrugs. As a biological validation of the $\mathrm{H}_{2} \mathrm{~S}$ prodrugs, the anti-inflammatory effects of one such prodrug were examined by studying its ability to inhibit LPS-induced TNF-a production in RAW 264.7 cells. This type of $\mathrm{H}_{2} \mathrm{~S}$ prodrugs shows great potential as both research tools and therapeutic agents.
\end{abstract}

\section{Keywords}

Hydrogen sulfide prodrugs; Enzyme trigger; Trimethyl lock; $\mathrm{H}_{2} \mathrm{~S}-\mathrm{NSAIDs}$; Lactonization; Antiinflammatory

\begin{abstract}
$\mathrm{H}_{2} \mathrm{~S}$ is an endogenously produced signaling molecule in mammals and is critical to human health and disease. ${ }^{[1]}$ Many studies have also shown the various therapeutic effects of $\mathrm{H}_{2} \mathrm{~S}$, which include protection against myocardial ischemia injury, cytoprotection against oxidative stress, mediation of neurotransmission, inhibition of insulin signaling, regulation of inflammation and dilation of blood vessel. ${ }^{[1 \mathrm{a}, 1 \mathrm{~b}, 1 \mathrm{~d}, 1 \mathrm{e}, 2]}$

In studying the physiological and pathological properties of $\mathrm{H}_{2} \mathrm{~S}, \mathrm{H}_{2} \mathrm{~S}$ gas or inorganic sulfide salts such as $\mathrm{Na}_{2} \mathrm{~S}$ and $\mathrm{NaHS}$ have been widely used. However, the uncontrollable release of $\mathrm{H}_{2} \mathrm{~S}$ from sulfide salts and the toxic effects of excessive $\mathrm{H}_{2} \mathrm{~S}$ limit their potential as possible therapeutic agents. ${ }^{[3]}$ Moreover, inorganic sulfide salts could not mimic the slow and continuous $\mathrm{H}_{2} \mathrm{~S}$ production in the biological system, which further limits their usage. Therefore, new $\mathrm{H}_{2} \mathrm{~S}$ releasing agents $\left(\mathrm{H}_{2} \mathrm{~S}\right.$ donors $)$ are of great clinical and research
\end{abstract}

\footnotetext{
aPatent pending covering Hydrogen Sulfide Precursors and Drug Conjugates Thereof Correspondence to: Binghe Wang, wang@gsu . edu.

Supporting information for this article is given via a link at the end of the document
} 
interests. ${ }^{[3-4]}$ Currently, there are seven types of $\mathrm{H}_{2} \mathrm{~S}$ donors that have been reported: ${ }^{[5]} 1$ ) garlic and related sulfur compounds; ${ }^{[6]}$ 2) Lawensson's reagent and analogs (GYY4137); ${ }^{[7]}$ 3) 1,2-dithiole-3-thiones (DTTs) and hybrids of $\mathrm{H}_{2} \mathrm{~S}$ and non-steroidal anti-inflammatory drugs; $;{ }^{[8]} 4$ ) thiol-activated $\mathrm{H}_{2} \mathrm{~S}$ donors; ${ }^{[9]}$ 5) photo-induced $\mathrm{H}_{2} \mathrm{~S}$ donors; ${ }^{[10]}$ and 6) thiol amino acid; ${ }^{[11]}$ and 7) polysulfide (SG-1002). ${ }^{[12]}$ There are some obvious limitations among these $\mathrm{H}_{2} \mathrm{~S}$ donors. First of all, the release rates of $\mathrm{H}_{2} \mathrm{~S}$ from most donors such as GYY4137 and DTTs are hard to control, and the effect of their byproducts associated with $\mathrm{H}_{2} \mathrm{~S}$ release is unclear. Furthermore, existing $\mathrm{H}_{2} \mathrm{~S}$ donor systems lack well defined negative controls. Some $\mathrm{H}_{2} \mathrm{~S}$ donors, such as thiol-activated $\mathrm{H}_{2} \mathrm{~S}$ donors would generate the perthiol intermediates, which may also have certain physiological effect, making it hard to deconvolute the experimental results. Almost all existing donors release precursors of $\mathrm{H}_{2} \mathrm{~S}$. Thus the correlation of $\mathrm{H}_{2} \mathrm{~S}$ release and the amount of donor added is difficult. $\mathrm{H}_{2} \mathrm{~S}$ donors that can mimic endogenous $\mathrm{H}_{2} \mathrm{~S}$ production through a single enzymatic step are currently not available. Recently, Moore et al ${ }^{[13]}$ tested the effect of GYY4137 on the release of proand anti-inflammatory mediators in lipopolysaccharide (LPS)-treated murine RAW264.7 macrophages, and found that the effects of $\mathrm{H}_{2} \mathrm{~S}$ on inflammatory processes are complex and dependent not only on $\mathrm{H}_{2} \mathrm{~S}$ donor concentration but also on the rate of $\mathrm{H}_{2} \mathrm{~S}$ generation. Therefore, there is a need for new $\mathrm{H}_{2} \mathrm{~S}$ prodrugs, which directly generate $\mathrm{H}_{2} \mathrm{~S}$ with welldefined and tunable release rates that are not directly affected by the redox balance of the cellular environment and the presence of other thiol species. Such $\mathrm{H}_{2} \mathrm{~S}$ donors/prodrugs will be very important research tools in delineating the functions of $\mathrm{H}_{2} \mathrm{~S}$ and lay a foundation for the future development of $\mathrm{H}_{2} \mathrm{~S}$-based therapeutics.

Our lab has long-standing interests in prodrugs based on intramolecular cyclizations. ${ }^{[14]}$. We took advantage of one such lactonization prodrug systems (Scheme 1), and designed esterase-sensitive prodrugs of $\mathrm{H}_{2} \mathrm{~S}$. Specifically, the nucleophilic hydroxyl or amino group can be masked as an ester or amide, and the drug, $\mathrm{H}_{2} \mathrm{~S}$, can be conjugated to the carbonyl carbon in the form of a thioacid. After hydrolysis of the masking group, the nucleophile can attack the carbonyl group and undergo a lactonization reaction, and thus release hydrogen sulfide.

To test the idea, we first synthesized prodrug BW-HP-101, which uses a "trimethyl lock" and thus stereochemical control to facilitate lactonization. ${ }^{[14 a, 15]}$ The synthesis of BWHP-101 was accomplished by treating compound $\mathbf{1},{ }^{[16]}$ with Lawensson's reagent under microwave conditions ${ }^{[17]}$ followed by reaction with one equivalent of sodium hydroxide (Scheme 2).

The novel BW-HP-101 is a very stable white and odorless solid, and has very good water solubility, allowing $10 \mathrm{mM}$ stock solutions to be prepared in aqueous buffer. The prodrug showed no obvious decomposition during storage at room temperature for 3 days and at $-20{ }^{\circ} \mathrm{C}$ for 3 month.

To examine the feasibility of concept described in Schemes 1 and 2, we studied whether esterase can catalyze $\mathrm{H}_{2} \mathrm{~S}$ release from BW-HP-101 by using a $\mathrm{H}_{2} \mathrm{~S}$-selective microelectrode, and found time-dependent $\mathrm{H}_{2} \mathrm{~S}$ release in the presence of porcine liver esterase (PLE) (Figure 1) with a peak concentration at about $15 \mathrm{~min} . \mathrm{H}_{2} \mathrm{~S}$ release was further 
confirmed by using a well-known hydrogen sulfide fluorescent probe WSP-5 ${ }^{[18]}$ (Figure 2). Strong fluorescence was detected when WSP-5 was incubated with the prodrug in the presence of PLE in phosphate buffer saline (PBS) or cell culture media containing fetal bovine serum (FBS). Such results indicate that BW-HP-101 indeed releases $\mathrm{H}_{2} \mathrm{~S}$ in PBS with esterase catalysis, or cell culture media containing FBS. In contrast, incubation in PBS alone did not lead to $\mathrm{H}_{2} \mathrm{~S}$ formation, indicating the chemical stability of the prodrug. Lactone formation was also confirmed by NMR (SI). As another piece of evidence on the stability of the thioacid group, thioactic acid was incubated in aqueous solution; no decomposition was observed within $48 \mathrm{~h}$ (SI).

All these studies demonstrate the expected enzyme-catalyzed release of hydrogen sulfide from the prodrug system. We then further studied the tunability of the release rates by varying the ester group and factors controlling the lactonization step. Variations of the ester group allows for tuning the rate of the unmasking step. For ester hydrolysis, it has been shown that increasing the size of the acyl moiety results in decreased catalytic hydrolysis rate. ${ }^{[19]}$ Thus we reasoned that modifying the acyl moiety should help tune the hydrolysis rates. The second direction in tuning $\mathrm{H}_{2} \mathrm{~S}$ releasing rates is based on controlling the lactonization rate by varying the number of methyl groups in the system. It is well known that the lactonization of compound $\mathbf{1}$ is much faster than that of o-hydroxydihydrocinnamic acids 3 and 4, which lack pendant methyl groups (Scheme 3) and thus has decreased entropic control of the conformation favorable for lactonization. ${ }^{[15 b]}$ Therefore, BWHP-102, -103, and -104 were synthesized to tune the release rates. BW-HP-102 and BWHP-104 contain a large acyl moiety cyclopropanecarbonyl ester and BW-HP-103 and BWHP-104 lack two methyl groups on phenyl ring.

$\mathrm{H}_{2} \mathrm{~S}$ release from these prodrugs was studied (Figure 3). As designed, these prodrugs show very different $\mathrm{H}_{2} \mathrm{~S}$ release rates. For $200 \mu \mathrm{M}$ of the prodrug in PBS at $37{ }^{\circ} \mathrm{C}$ with 1 unit $/ \mathrm{mL}$ PLE, the peak $\mathrm{H}_{2} \mathrm{~S}$ concentration for the fastest one, BW-HP-101, was about $95 \mu \mathrm{M}$ at 15 $\mathrm{min}$; and for the slowest one, BW-HP-104, it was about $13 \mu \mathrm{M}$ at $43 \mathrm{~min}$. Such results bring out an important issue, i.e. the same concentration of the prodrug may mean very different effective $\mathrm{H}_{2} \mathrm{~S}$ concentrations, depending on the release rates. This issue is especially important in delivering a gaseous molecule because of its volatility nature and the lack of "accumulation," which is in direct contrast to the delivery of non-volatile drugs. In the latter case, a slower release may only affect the onset time, but not the final concentration. With a gaseous molecule, release rates affect the onset time, the peak concentration, and the eventual concentration significantly. Thus when comparing the results using various $\mathrm{H}_{2} \mathrm{~S}$ prodrugs/donors, particular attention needs to be paid to the release rate and effective concentration issue.

We also monitored the lactone product formation by HPLC (Table 1 ), and found $\mathrm{t}_{1 / 2}$ ranging from 13 to $99 \mathrm{~min}$ for $200 \mu \mathrm{M}$ prodrugs in the presence of PLE. Such results further demonstrated the concept of tuning the $\mathrm{H}_{2} \mathrm{~S}$ release rates.

The conjugation of two drugs with the same therapeutic indication, but different mechanisms, is attracting a great deal of attention in the hybrid drug field. ${ }^{[21]}$ Especially interesting is the idea of conjugating a non-steroidal anti-inflammatory drug (NSAID) to a 
$\mathrm{H}_{2} \mathrm{~S}$ donor, ${ }^{[22]}$ which has known anti-inflammatory effects. $\mathrm{H}_{2} \mathrm{~S}$-NSAIDs have shown remarkable improvements in activity and tolerability as compared with the related parent compounds. ${ }^{[21]}$ However, few of the hydrogen sulfide prodrugs could be successfully applied to hybrid drug preparation for chemistry reasons, and existing $\mathrm{H}_{2} \mathrm{~S}-\mathrm{NSAIDs}$ also suffer from the lack of control in $\mathrm{H}_{2} \mathrm{~S}$ release. Because most NSAIDs have a free carboxyl group, their conjugation to one of our prodrugs is not only easy, but also leads to a hybrid prodrug, which uses the same mechanism to release both drugs. This is very unique among all known $\mathrm{H}_{2} \mathrm{~S}$ hybrid drugs. Thus, we also synthesized BW-HP-105, which is formed by coupling the novel $\mathrm{H}_{2} \mathrm{~S}$ release system to naproxen (Figure 4). HPLC kinetic studies showed that BW-HP-105 could generate naproxen and $\mathrm{H}_{2} \mathrm{~S}$ by treatment with an esterase. Compared to other $\mathrm{H}_{2} \mathrm{~S}$ prodrugs with the same stereochemical control (BW-HP-101, 102), BWHP-105 showed a slower hydrolysis rate as expected because of the larger masking group (naproxen as the acyl group). The $\mathrm{H}_{2} \mathrm{~S}-\mathrm{NSAID}$ hybrid shown here is the first example of controllable $\mathrm{H}_{2} \mathrm{~S}$ release employing the same mechanism to "activate" both drugs, and will be a very useful research tool and potential therapeutic agent.

We next tested whether such compounds also produced $\mathrm{H}_{2} \mathrm{~S}$-associated biological effects in vitro. For such studies, negative control compounds are always important. However, there are no good control compounds for existing $\mathrm{H}_{2} \mathrm{~S}$ prodrugs. To address this issue, we used the inactive oxyacid version of the prodrugs (iHPs, Figure 3 ) as the control compounds.

Compared to thioacid prodrugs, iHPs have the same chemical structural frame except replacing sulfur with oxygen.

We first tested the cytotoxicity of these prodrugs on RAW264.7 macrophages. None showed any toxicity at $200 \mu \mathrm{M}$ (See Supporting Information). We then examine the effect of the prodrugs on TNF-a production after co-treatment of the cell with the prodrugs and $1 \mu \mathrm{g} / \mathrm{mL}$ LPS for one hour, using an ELISA kit (Figure 5). The results showed that only the prodrugs and GYY 4137 effectively inhibited TNF-a secretion, and $\mathrm{Na}_{2} \mathrm{~S}$ showed pro-inflammatory effect, which is similar to literature results. ${ }^{[13]}$ None of the iHPs showed the same effect, which clearly demonstrated that the inhibition effect on TNF-a production came from the $\mathrm{H}_{2} \mathrm{~S}$ released from the respective prodrug.

In conclusion, we successfully investigated a new strategy of making $\mathrm{H}_{2} \mathrm{~S}$ prodrugs by using an esterase catalyzed lactonization prodrug system. Compared to existing $\mathrm{H}_{2} \mathrm{~S}$ prodrugs/ donors, the new $\mathrm{H}_{2} \mathrm{~S}$ prodrugs described show several unique features. First of all, they have controlled $\mathrm{H}_{2} \mathrm{~S}$ release rates. This aspect seems to be the most challenging and important issue in the field of $\mathrm{H}_{2} \mathrm{~S}$ donors. Secondly, the trigger is an enzyme ubiquitous in the biological system. ${ }^{[23]}$ Thirdly, the prodrugs require a specific type of enzyme to trigger $\mathrm{H}_{2} \mathrm{~S}$ release, which afford the potential for controlled release at preferred sites. Fourthly, as research tools, the prodrugs described have well-defined negative controls. Fifthly, this strategy provides the first $\mathrm{H}_{2} \mathrm{~S}$-NSAIDs hybrids with controllable release rates. We believe that these new $\mathrm{H}_{2} \mathrm{~S}$ prodrugs will be very useful research tools to others working in this field. 


\section{Supplementary Material}

Refer to Web version on PubMed Central for supplementary material.

\section{Acknowledgments}

Financial support from the NIH (CA180519) is gratefully acknowledged.

\section{References}

1. a) Vandiver MS, Snyder SH. J Mol Med (Berl). 2012; 90:255-263. [PubMed: 22314625] b) Szabo C. Nat Rev Drug Discov. 2007; 6:917-935. [PubMed: 17948022] c) Wang R. Physiol Rev. 2012; 92:791-896. [PubMed: 22535897] d) Blackstone E, Morrison M, Roth MB. Science. 2005; 308:518. [PubMed: 15845845] e) Lowicka E, Beltowski J. Pharmacol Rep. 2007; 59:4-24. [PubMed: 17377202] f) Bohlender C, Glaser S, Klein M, Weisser J, Thein S, Neugebauer U, Popp J, Wyrwa R, Schiller A. J Mater Chem B. 2014; 2:1454-1463.

2. a) Calvert JW, Coetzee WA, Lefer DJ. Antioxid Redox Signal. 2010; 12:1203-1217. [PubMed: 19769484] b) Gadalla MM, Snyder SH. J Neurochem. 2010; 113:14-26. [PubMed: 20067586] c) Martelli A, Testai L, Citi V, Marino A, Bellagambi FG, Ghimenti S, Breschi MC, Calderone V. Vascul Pharmacol. 2014; 60:32-41. [PubMed: 24287004] d) Testai L, Martelli A, Marino A, D’Antongiovanni V, Ciregia F, Giusti L, Lucacchini A, Chericoni S, Breschi MC, Calderone V. Biochem Pharmacol. 2013; 85:1634-1643. [PubMed: 23567997] e) Ahmad A, Olah G, Szczesny B, Wood ME, Whiteman M, Szabo C. Shock (Augusta, Ga). 2015

3. a) Kashfi K, Olson KR. Biochem Pharmacol. 2013; 85:689-703. [PubMed: 23103569] b) Zhao Y, Biggs TD, Xian M. Chem Commun (Camb). 2014; 50:11788-11805. [PubMed: 25019301]

4. a) Song ZJ, Ng MY, Lee ZW, Dai W, Hagen T, Moore PK, Huang D, Deng LW, Tan CH. Med Chem Commun. 2014; 5:557-570.b) Pluth MD, Bailey TS, Hammers MD, Hartle MD, Henthorn HA, Steiger AK. Synlett. 2015; 26:2633-2643.

5. Zheng Y, Ji X, Ji K, Wang B. Acta Pharm Sin B. 2015; 5:367-377. [PubMed: 26579468]

6. a) Benavides GA, Squadrito GL, Mills RW, Patel HD, Isbell TS, Patel RP, Darley-Usmar VM, Doeller JE, Kraus DW. Proc Natl Acad Sci U S A. 2007; 104:17977-17982. [PubMed: 17951430] b) Liang D, Wu H, Wong MW, Huang D. Org Lett. 2015; 17:4196-4199. [PubMed: 26301500]

7. Li L, Whiteman M, Guan YY, Neo KL, Cheng Y, Lee SW, Zhao Y, Baskar R, Tan CH, Moore PK. Circulation. 2008; 117:2351-2360. [PubMed: 18443240]

8. a) Baskar R, Sparatore A, Del Soldato P, Moore PK. Eur J Pharmacol. 2008; 594:1-8. [PubMed: 18680741] b) Qandil AM. Int J Mol Sci. 2012; 13:17244-17274. [PubMed: 23247285]

9. a) Zhao Y, Wang H, Xian M. J Am Chem Soc. 2011; 133:15-17. [PubMed: 21142018] b) Zhao Y, Bhushan S, Yang C, Otsuka H, Stein JD, Pacheco A, Peng B, Devarie-Baez NO, Aguilar HC, Lefer DJ, Xian M. ACS Chem Biol. 2013; 8:1283-1290. [PubMed: 23547844] c) Martelli A, Testai L, Citi V, Marino A, Pugliesi I, Barresi E, Nesi G, Rapposelli S, Taliani S, Da Settimo F, Breschi MC, Calderone V. ACS Med Chem Lett. 2013; 4:904-908. [PubMed: 24900583]

10. a) Devarie-Baez NO, Bagdon PE, Peng B, Zhao Y, Park CM, Xian M. Org Lett. 2013; 15:27862789. [PubMed: 23697786] b) Fukushima N, Ieda N, Sasakura K, Nagano T, Hanaoka K, Suzuki T, Miyata N, Nakagawa H. Chem Commun (Camb). 2014; 50:587-589. [PubMed: 24280741]

11. Zhou Z, von Wantoch Rekowski M, Coletta C, Szabo C, Bucci M, Cirino G, Topouzis S, Papapetropoulos A, Giannis A. Bioorg Med Chem. 2012; 20:2675-2678. [PubMed: 22436388]

12. Kondo K, Bhushan S, King AL, Prabhu SD, Hamid T, Koenig S, Murohara T, Predmore BL, Gojon G, Gojon G, Wang R, Karusula N, Nicholson CK, Calvert JW, Lefer DJ. Circulation. 2013; 127:1116-1127. [PubMed: 23393010]

13. Whiteman M, Li L, Rose P, Tan CH, Parkinson DB, Moore PK. Antioxid Redox Signal. 2010; 12:1147-1154. [PubMed: 19769459]

14. a) Shan D, Nicolaou MG, Borchardt RT, Wang B. J Pharm Sci. 1997; 86:765-767. [PubMed: 9232513] b) Wang B, Zhang H, Wang W. Bioorg Med Chem Lett. 1996; 6:945-950.c) Zych L, Yang W, Griffin K, Liao Y, Wang B. Bioorg Chem. 2004; 32:109-123. [PubMed: 14990309] 
15. a) Borchardt RT, Cohen LA. J Am Chem Soc. 1972; 94:9175-9182. [PubMed: 4642367] b)

Borchardt RT, Cohen LA. J Am Chem Soc. 1972; 94:9166-9174. [PubMed: 4642366] c) Amsberry KL, Borchardt RT. J Org Chem. 1990; 55:5867-5877.d) Amsberry KL, Borchardt RT. Pharm Res. 1991; 8:323-330. [PubMed: 2052518] e) Schowen KB, Schowen RL, Borchardt SE, Borchardt PM, Artursson P, Audus KL, Augustijns P, Nicolazzo JA, Raub TR, Schöneich C, Siahaan TJ, Takakura Y, Thakker DR, Wolfe MS. J Pharm Sci. 2016; 105 published on-line. doi: $10.1002 /$ jps. 24687

16. Amsberry KL, Gerstenberger AE, Borchardt RT. Pharm Res. 1991; 8:455-461. [PubMed: 1871039]

17. Rao Y, Li X, Nagorny P, Hayashida J, Danishefsky SJ. Tetrahedron lett. 2009; 50:6684-6686. [PubMed: 20160926]

18. Peng B, Chen W, Liu C, Rosser EW, Pacheco A, Zhao Y, Aguilar HC, Xian M. Chemistry. 2014; 20:1010-1016. [PubMed: 24339269]

19. a) Elleby B, Sjoblom B, Lindskog S. Eur J Biochem. 1999; 262:516-521. [PubMed: 10336637] b) Roberts TK, Masson PL, Lauwerys R, Heremans JF. Andrologia. 1976; 8:67-71. [PubMed: 952420]

20. a) Levine MN, Raines RT. Chem Sci. 2012; 3:2412-2420. [PubMed: 23181187] b) Shan D, Nicolaou MG, Borchardt RT, Wang B. J Pharm Sci. 1997; 86:765-767. [PubMed: 9232513] c) Milstien S, Cohen LA. Proc Natl Acad Sci U S A. 1970; 67:1143-1147. [PubMed: 5274444] d) Milstien S, Cohen LA. J Am Chem Soc. 1972; 94:9158-9165. [PubMed: 4642365]

21. Sparatore A, Santus G, Giustarini D, Rossi R, Del Soldato P. Expert Rev Clin Pharmacol. 2011; 4:109-121. [PubMed: 22115352]

22. Li L, Rossoni G, Sparatore A, Lee LC, Del Soldato P, Moore PK. Free Radic Biol Med. 2007; 42:706-719. [PubMed: 17291994]

23. Bahar FG, Ohura K, Ogihara T, Imai T. J Pharm Sci. 2012; 101:3979-3988. [PubMed: 22833171] 


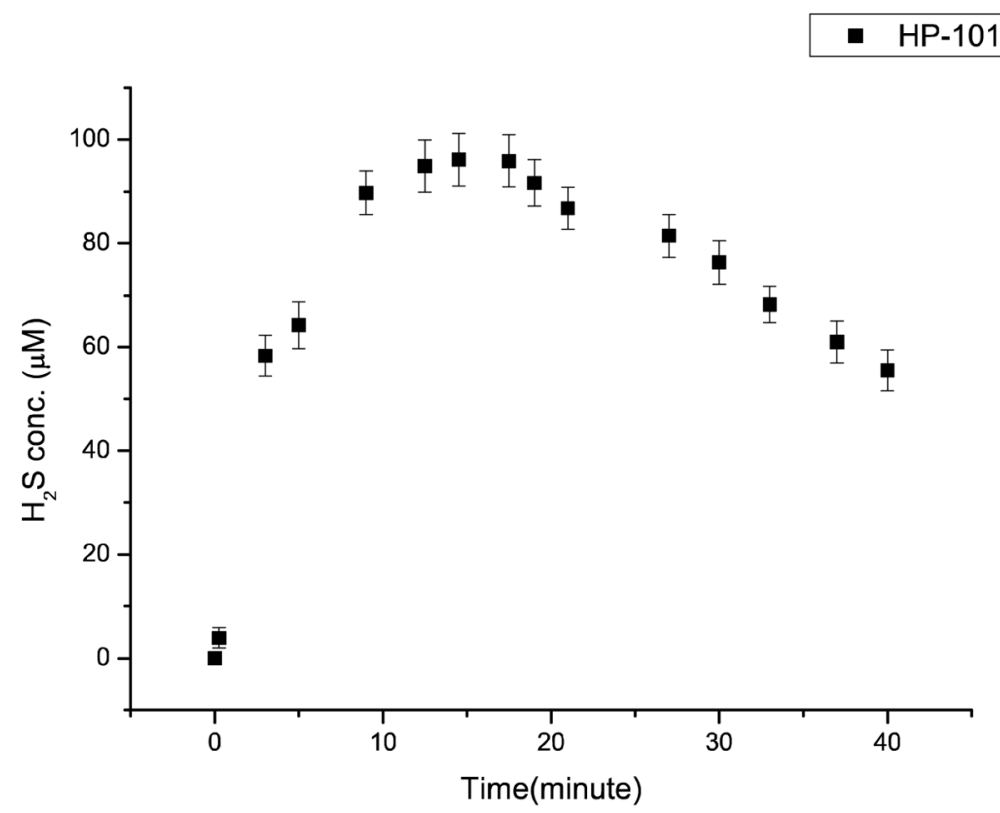

Figure 1.

Hydrogen sulfide generation from BW-HP-101. $200 \mu \mathrm{M}$ the prodrug in PBS (1\% DMSO) at $37{ }^{\circ} \mathrm{C}$ with $1 \mathrm{unit} / \mathrm{mL}$ of PLE. $(\mathrm{p}=0.95, \mathrm{n}=3$.) 


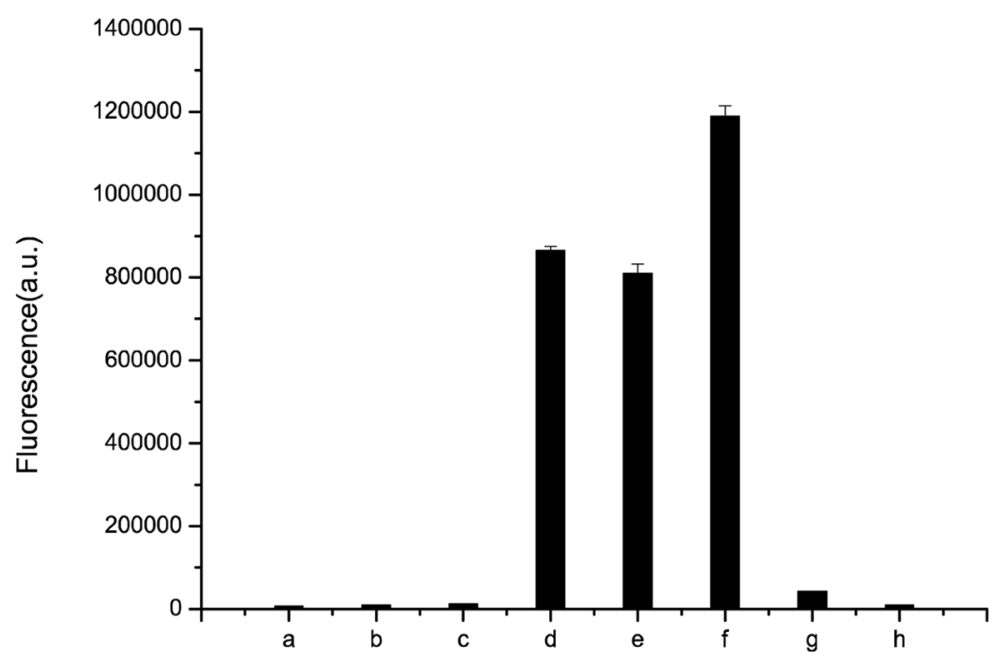

Figure 2.

Qualitatively detection of hydrogen sulfide releasing from BW-HP-101 by WSP-5. The concentration of WSP-5 is $50 \mathrm{uM}$, and the intensities of fluorescence were recorded after 5 min of incubation of WSP-5 with different substrates at room temperature. a: WSP-5 only in PBS; b: WSP-5+ $200 \mu \mathrm{M}$ prodrug in PBS; c: WSP-5+ $200 \mu \mathrm{M}$ prodrug in DMEM (No FBS), no cells; d: WSP-5+ $200 \mu \mathrm{M}$ prodrug in DMEM (with FBS)+ cells e: WSP-5+ 200 $\mu \mathrm{M}$ prodrug in DMEM (with FBS), no cells; f: WSP-5+ $200 \mu \mathrm{M}$ prodrug $+1 \mathrm{unit} / \mathrm{mL}$ of esterase; g: WSP-5+200 $\mu$ M GYY1437; h: WSP-5+1unit/mL esterase. 

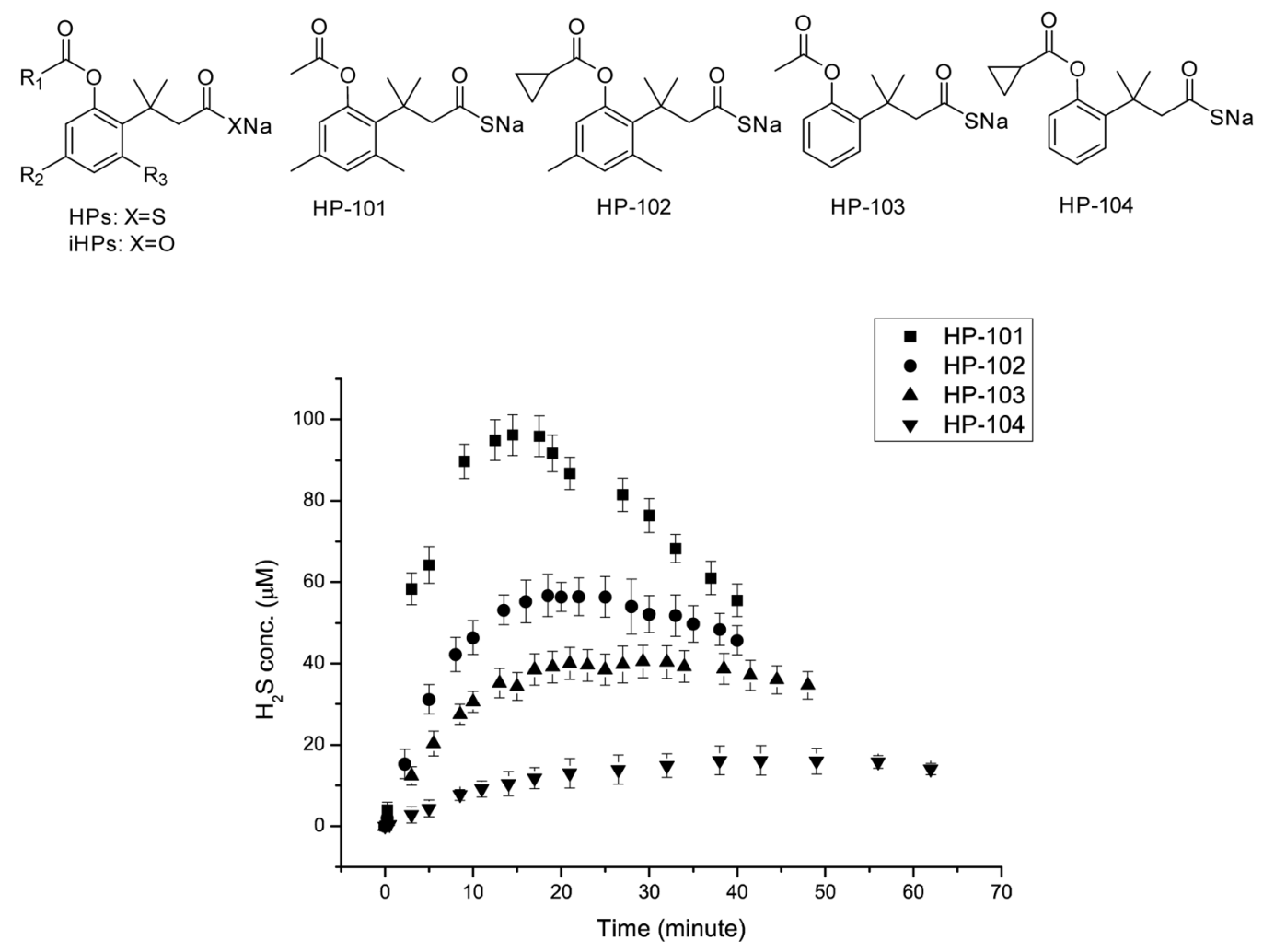

Figure 3.

$\mathrm{H}_{2} \mathrm{~S}$ generation curves. $200 \mu \mathrm{M}$ prodrugs in PBS (1\% DMSO) with 1 unit/mL esterase at $37^{\circ} \mathrm{C} .(\mathrm{p}=0.95, \mathrm{n}=3$. 

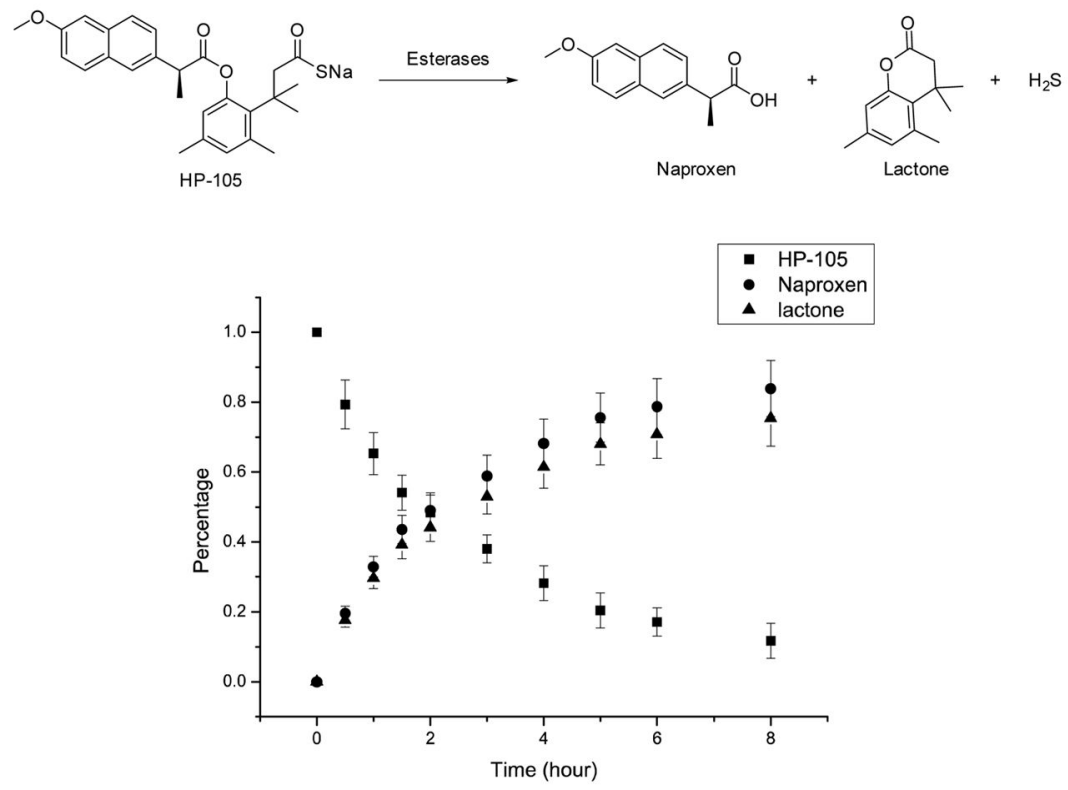

Figure 4.

$200 \mu \mathrm{M}$ HP-105 in PBS (1\% DMSO) with esterase 20 unit/mL at $37^{\circ} \mathrm{C}$. $(\mathrm{p}=0.95, \mathrm{n}=3$. $)$ 
(A)

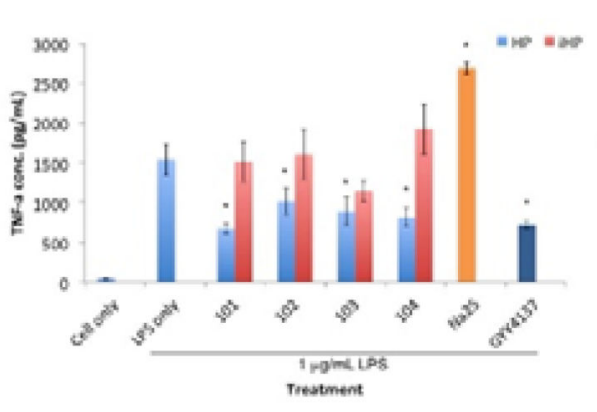

(B)

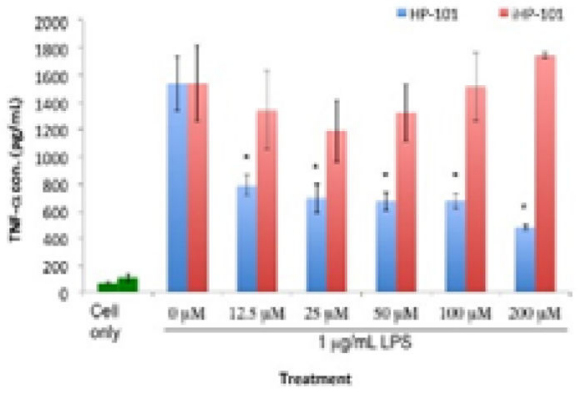

Figure 5.

TNF-a concentrations of RAW 264.7 cell culture media after 1-hour co-treatment with $\mathrm{H}_{2} \mathrm{~S}$ prodrugs and LPS. (A) Treatment with $50 \mu \mathrm{M}$ HPs, iHPs $\mathrm{Na}_{2} \mathrm{~S}$ and GYY4137. (B)

Treatment with various concentrations of BW-HP-101 and iHP-101 ( $n=4 *$ : $p<0.05)$ 


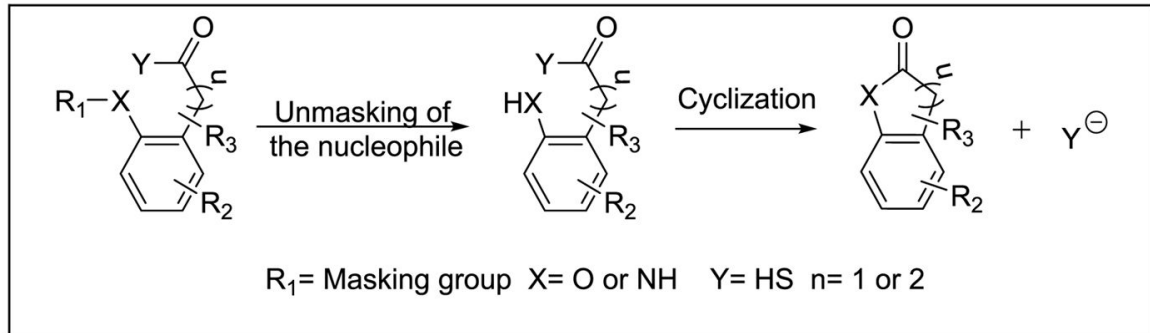

Scheme 1.

The general concept of cyclization driven prodrugs of hydrogen sulfide 

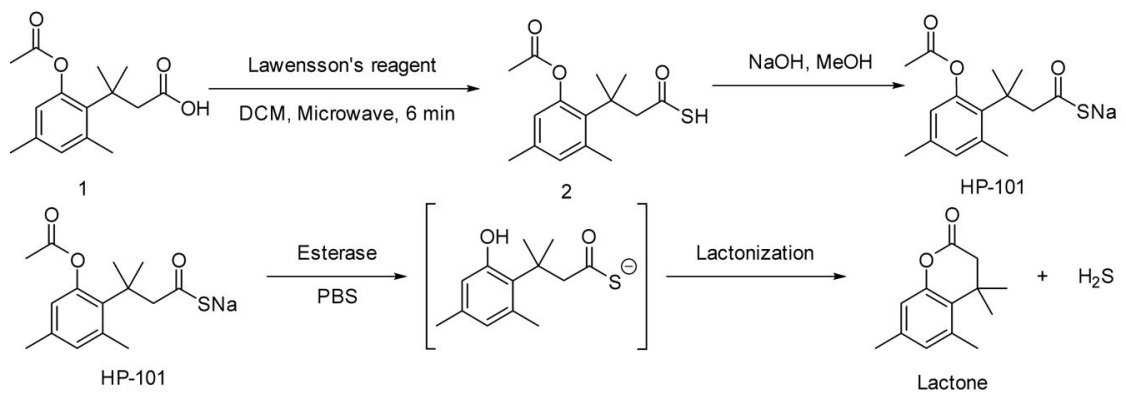

Scheme 2.

Synthesis of "trimethyl lock"-based $\mathrm{H}_{2} \mathrm{~S}$ prodrug HP-101 and the mechanism of esterase triggered $\mathrm{H}_{2} \mathrm{~S}$ release 


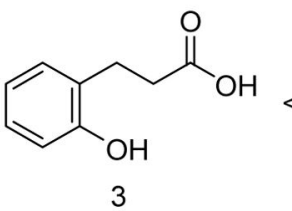

$k^{\prime}$ rel

1

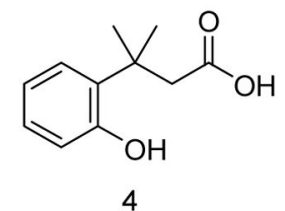

4400

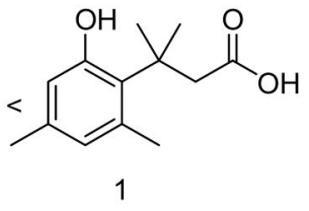

$5.1 \times 10^{10}$

Scheme 3.

Relative rate constants for lactonization of various hydroxydihydrocinnamic acids. [20] 


\section{Table 1}

The half-lives of various prodrugs. $200 \mu \mathrm{M}$ prodrugs in PBS with esterase $1 \mathrm{unit} / \mathrm{mL}$ at $37^{\circ} \mathrm{C}, \mathrm{p}=0.95, \mathrm{n}=3$.

\begin{tabular}{|c|c|c|c|c|}
\hline & BW-HP-101 & BW-HP-102 & BW-HP-103 & BW-HP-104 \\
\hline $\mathrm{T}_{1 / 2}(\mathrm{~min})$ & $13.0 \pm 2.4$ & $28.7 \pm 1.5$ & $44.5 \pm 2.1$ & $99.0 \pm 8.9$ \\
\hline
\end{tabular}

